\title{
Putnička tekstualnost u postdisciplinarnom ozračju
}

\author{
Dean Duda, Kultura putovanja: uvod u književnu iterologiju, \\ Naklada Ljevak, Zagreb 2012, ss. 236
}

Otkad je ponarasla svijest da je književnost u mnogolikim povijesnim promjenama uvelike mijenjala svoj institucionalni status, pa i zasebna svojstva, ovisno već o raznolikim funkcijama i položajima u odnosu na diskurse koji su je okruživali, s kojima je rubila, drugovala i ratovala, i književno-znanstvena je praksa postala sve gibljivije i uznemirenije poprište koje odgovara na sve razvedenije problemske nagovore i na kojemu stoga druguju raznovrsna znanja, pa se i zainteresiranoj publici na njemu sve teže snaći. Da se s poslom vodiča u tome neophodnom snalaženju kadar okretno nositi, pokazao je komparatist Dean Duda već svojim Uvodom u kulturalne studije, pa će se i Kultura putovanja, to jest uvod u književnu iterologiju, dočekati s punim povjerenjem u pouzdanost njegove kompetencije i vještine izlaganja, kvalitete koje knjiga nedvoumno potvrđuje, kao važan doprinos u nas posve novome književno-istraživačkom području.

Trenutak u kojemu putovanje dospijeva u žarište humanističke refleksije rječito svjedoči o promjeni ideološkog naglaska, promjeni, veli Duda, mjere svijeta, o duhu skepse prema simbolima ukorijenjenosti, ognjištu i rodnoj grudi, pa je sklon egzaltirati vrijednosti avanture, potrage, ne-smjestivosti, a s njime i tako nerijetko egzistencijalno bolna, duboko ekonomski i politički uvjetovana iskustva kao što su egzil i nomadizam pa čak i ta iskustva pretvarati u povlaštene metafore suvremenih subjektnih pozicija, kao što je primjerice ženski nomadski subjekt talijanske filozofkinje Rosi Braidotti. Tako ni ova knjiga, koja svojom atraktivnom naslovnicom kao da sugerira lakoću odluke da se spakira najnužnije i dade na put, ipak sama nije nipošto lako štivo, neki suvremeni teorijski bedeker koji će se ulagivati tipičnim asocijacijama koje se bilo po malograđanskoj ili bogatunskoj navici običavaju uz putovanje vezivati, asocijacijama dokolice, 
avanture i egzotike, pa nam svojim olakim smjerokazima laskavo promovirati putovanje i u intelektualno i literarno legitimiran fenomen. Dapače, koliko god da je nesumnjivo studij popularne kulture kojim se Duda sustavno bavi jedno od zakonitih zakloništa diskusije o kulturi putovanja, i ovom mu je prilikom stalo da predmet svojeg interesa istrgne iz bestežinskih sfera eskapizma, utopije i zabave, kao i da ne dopusti da on potone u moru svaštarija koje bi se tim povodom mogle istraživati i metodoloških očitosti kojima se kulturni studiji katkad znadu krasiti, uvelike i zaboravljajući na protokole koje im je svojedobno nametnula birminghamska škola.

Umjesto toga, inzistirat će na istraživačkoj složenosti i zahtjevnosti svojega predmeta, na širokom rasponu toga fenomena, od materijalnih, organizacijskih i tehnoloških pretpostavki - načina i sredstava putovanja, njegovih odmorišta i konačišta - do njegovih prizemnih, grabežnih, kolonijalnih, ili pak uzvišenih, spiritualnih i slobodarskih motivacija, do statusnog indeksa njegovih odredišta, a onda i njegovih tegobnijih prisilnih ili prekarnih okolnosti, kada su u pitanju migracije, progonstvo i izbjeglištvo. Duda se kroz sve te prostorne i vremenske slojeve i odvojke svoje problematike probija s lakoćom, nudeći uvijek svježe, ažurirane asocijacije i prispodobe, oslonjen na pretpostavku kako je posrijedi ipak fenomen dugog trajanja, kojemu su se doduše smjenjivali ideološki naglasci i progresivno olakšavala infrastrukturna podrška, no koji u osnovi nije izgubio svoj karakter temeljne ljudske uvjetovanosti.

Ispostavlja se stoga da je putovanje ogledno poprište postdisciplinarnog interesa, neizbježnog križanja paralelnih disciplinarnih svjetova antropologije, sociologije, politologije, filozofije, ekonomije i kulturne geografije, kojima se pak sa svoje strane pridružuje i književna iterologija, naziv koji Duda preuzima od Michela Butora, dakle izučavanje pitanja na koji način književnost i književna znanost participiraju u tome složenome prepletu pristupa. Pored svoje postdisciplinarne potentnosti, putovanje izniče, kaže autor, i kao logičan interesni ishod triju obrata humanističkoga izučavanja, kulturalnog, u smislu u kojem ga je zacrtao Raymond Williams sa svojom podjelom na idealnu, dokumentarnu i socijalnu definiciju kulture, zatim spacijalnog obrata Edwarda Soje, pomaka interesa s vremena i povijesti na prostorno-geografska ljudska oblikovanja i izmještanja te naposljetku obrata prema mobilnosti, metafori koja je počela prožimati izuča- 
vanja različitih društvenih sfera, od profesionalnih do političkih, koja je dapače samu društvenost počela poimati kao temeljno obilježenu pokretljivošću i nestabilnošću.

Knjiga je podijeljena u pet opsežnih poglavlja: prvo će zacrtati usjek što ga je književni strukovnjak pozvan pronaći u prethodno dočaranoj postdisciplinarnoj osjetljivosti za sve facete fenomena, dok će se preostala četiri kretati četirima povijesnim razdobljima, razmjerno homogenim putničkim kulturama antike i srednjeg vijeka, zatim progresivno kompliciranijim motivacijskim sklopom novovjekovlja, a naposljetku i modernim dobom kojemu je svojstvena konfliktnost različitih silnica s jedne strane omasovljenja, a s druge individualizacije putničkih aktivnosti, a koje traje od sredine 19. stoljeća do danas. Antički koncept putovanja ovdje se razlaže prvenstveno kroz prizmu fikcijske književnosti, iako je u pitanju razmjerno marginalni žanr za ono vrijeme, grčki ljubavni roman, i to roman Hereja i Kaliroja, za koji se tvrdi da oprimjeruje dominantnu mentalnu figuru putovanja za to razdoblje, a to je figura bolne odcijepljenosti, razdvojenosti, trpnje, kušnje, dakle figura pokoravanja nuždi i sudbini, a ne izraz slobode, bijega i užitka. Putovanje u antičkome svjetonazoru naime ne vodi u transformaciju, nego teži povratku i obnovi odnosa kakvi su vladali na početku, re-afirmaciji uloga koje je putovanje ugrozilo i dovelo u neravnotežu. Srednji vijek koncipirat će pak putovanje kao duhovno odmetništvo od stega ovozemaljskih prisila, ali bit će bitno obilježeno jednim ključnim tekstom, Biblijom, koja će uspostaviti njegovu geografiju, obilježiti mjesta, jamčiti putovanje kao vjersko iskustvo. U novovjekovlju putovanje sve više postaje stvar i političke i osobne znatiželje, diplomatsko špijunskog, osvajačkog ili pak intelektualno otvorenog upoznavanja s drugim svjetovima, prilika za stjecanje znanja i za vlastitu samospoznaju, dok će moderno doba upoznati kulturu dokolice, turizam i njegovo omasovljenje, umnožavanje različite putničke tekstualnosti, ali i tvorbu putničkih subjekata koji će polagati pravo na ekskluzivitet, kritički osvrt na matičnu sredinu iz perspektive putničkog odredišta, koji će rangirati vrijednost putničkih interesa, subjekata kakve u matičnoj putopisnoj praksi Duda pronalazi u Matošu i Krleži.

Njegova se podjela ne podudara s periodizacijama koje primjerice nude istraživanja fokusirana isključivo na turistički aspekt putovanja, već nastoji ne samo obuhvatiti puno složeniji sklop putničkih pobuda - od 
religijskih do osvajačkih nego i prije svega voditi računa o kompleksnim mijenama njihove književne pratnje, unutar koje, kako čusmo, svoje mjesto nalazi i niz hrvatskih primjera, počevši s Hektorovićevim Ribanjem i ribarskim prigovaranjem, iznimnim ranonovovjekovnim primjerom privremenog izmještanja za volju imaginacijske tvorbe reklo bi se utopijske zajednice visoke i pučke kulture, svojevrsna kulturološkog štita podignutog u pravcu prijeteće turske najezde. Smještajući dakle svoj primarno književni interes u opisano polje dinamičnih teorijskih razmjena, Duda će preuzeti poimanja kulture putovanja koja u njoj vide procesuiranje ne samo povijesno različitih vrijednosti i značenja što se putovanju mogu pridavati nego i punopravno bojno polje društvenih sukoba, odnosa ekonomske, političke pa čak i moralne moći, oblikovanja različitih klasnih, rasnih, dobnih i rodnih identiteta i njihovih nejednakih pristupa pravima i potrebama koje putovanje može ostvarivati i buditi. Posebno se stoga ističe položaj ženskog lika nad kojim se u knjizi nadvija sjena mitskog para Odiseja i Penelope: žena ne putuje, žena čeka, jer putovanje je oblik muškog života, iako je žena u antici ostvarivala neku minimalnu pokretljivost u religijskog praksi - u čemu možemo vidjeti dozvolu koja se izdaje samo za volju viših ciljeva zajednice, ali nipošto osobnoga ostvarivanja, avanture i lutanja - žena se ipak uvijek javlja kao sigurna luka, sidrište i pristanište, žena je znak za receptivnost, dom, vjernost, kuću, zatvorene, a ne otvorene prostore te utoliko uvijek putovanje može doživjeti samo u uvjetima ratnog poraza, ropstva, gubitka slobode, egzila i na putovanje otići samo u svojstvu onoga koji trpi, ne koji incira.

Takvo stanje vrijedi sve do prosvjetiteljstva, jer se s demokratizacijom i omasovljenjem putovanja ta patrijarhalna matrica počinje osporavati, no zasigurno ne i posve gubiti na snazi, kao što rječito potvrđuje baš jedan kasniji ženski književni lik, Ana Karenjina, kojoj će upravo odlazak na put otvoriti oči i razoriti brak. Međutim kad se već ovako kratkopotezno šećemo kroz povijesna razdoblja kroz ovu uzanu žensku nit, valja spomenuti i jednu zanimljivost, a to su dva primjera hodočasničkih putopisa srednjega vijeka: i dok je prvi hodočasnički putopis, Itinerarium Burdgalense, anonimna autorstva, ipak nizom svojih motiva, kao što su obavijesti vezane uz vodu i zečeće, trudnoću i djecu, a i posjeta lokacijama svojstvenima ženskim biblijskim likovima, daje povodom hipotezi da ga je ispisala jedna žena, koja je možda pratila muža na putovanju. S druge strane, potvrđeno 
žensko autorstvo tako zvani Egerijinog Putopisa, Itinerariuma, to jest Peregrinatia, smatra se jednim od najznačajnijih tekstova ranokršćanske kulture putovanja: zanimljivo je da se tu autorica obraća svojim sestrama, možda isto redovnicama ili gorljivim kršćankama, kako bi i one mogle posredno uživati u onome što je njoj omogućeno te da u svoj tekst uklapa ranokršćansku inačicu matrice grčkog ljubavnog romana o svetoj Tekli, gotovo tim postupcima pretvarajući svoj putopis u autentično žensko pismo.

Uvidu u mnogostruke značenjske i vrijednosne facete kulture putovanja međutim ne pomaže samo autorov izvrstan uvid u stvarne analitičke uloge i reklo bi se demistifikacijske ambicije kulturnostudijskog impetusa, kao i u njegove nužne transformacije pod udarom spomenutih obrata i humanističkih zaokreta, nego i njegova višejezična kompetencija, a s njome i mogućnost da se kritički osvrne na to kako su različite nacionalne sredine kao što su ne samo angloamerička nego i njemačka i francuska, akademski promišljale fenomen kulture putovanja. Upravo ga dakle takvo dobro poznavanje višestrukih dodira kojima su izložena različita znanja koja se oko kulture putovanja ukrštaju vode zaključku kako je to fenomen obilježen svojevrsnim dijaloškim viškom, kako iznuđuje stanoviti korektivni mehanizam za različite disciplinarne ukopanosti i ograničenja. Svjestan međutim zamki u koje može upasti nasumično i neutemeljeno postdisciplinarno lutanje raznolikim krajolicima priručnih floskula iz različitih humanističkih i društvenih područja, Duda na djelu pokazuje što znači biti odgovoran putnik paralelnim svjetovima i njihovim normama: želi li se naime književni znanstvenik, povjesničar ili teoretičar pozabaviti udjelom književnosti u formiranju putničkoga imaginarija, ili pak obratno, mjestom putničkog imaginarija u književnim svjetovima, morat će, tvrdi autor, uvijek voditi računa o njezinoj dvostrukoj artikulaciji, njezinoj navlastitoj obvezanosti književnim epohama, stilovima, žanrovima, obrascima i modusima, koliko i njezinoj navlastitoj dijaloškoj otvorenosti za različite osobne, kolektivne, kulturno-identitetske i komercijalne manipulacije i uporabe.

Logično, kao žanrovski kralj u tome dijalogu pokazat će se putopis, no način na koji Duda pozicionira putopis u odnosu na s jedne strane matično književno okružje, a s druge u odnosu na ine osobne relikte putničkih iskustava kao što su eseji, pisma, dnevnici ili kasnije razglednice, kolekcije fotografija i suvenira, ili pak namjenski putnički tekstovi kao što su diplo- 
matska i špijunska izvješća, medicinski i praktični savjetnici ili suvremeniji vodiči i priručnici, sjajno osvjetljuje koliko je i samom njegovom užem području interesa svojstvena statusna gibljivost: putopis je razmjerno ruban žanr u kontekstu književne genologije, ali u kontekstu putničke tekstualne produkcije za sobom vuče književni ugled i utjecaj, baca svjetlo na putničke topose unutar književnih svjetova kakvi su spomenuti starogrčki ljubavni romani, kojima će matrica, kako već čusmo, preživjeti i u kasnijim stoljećima i koji će uvelike diktirati načine na koji će putovanje prožeti romanesknu produkciju uopće.

Putovanje će se ovdje dakle prometnuti ne samo u krunsko obilježje zahtjeva što ga književnost postavlja pred čitatelja nego i u osovinski zalog priče, kako je to naukovao već semiotičar Lotman kada upozorava da priča mora započeti prekoračenjem neke granice. Zauzvrat pak, kaže Duda kada evocira Odisejev susret s Penelopom, putovanje ne može bez pripovijedanja, pa zato i priskrbljuje pripovjedni kapital: put zapravo malo vrijedi kada o njemu ne možemo nekome pričati pa makar pritom malo i izmišljali.

Lada Čale Feldman 